\title{
Oldest records of Bombyliidae: Phthiriinae and Mythicomyiidae: Glabellulinae from the Lowermost Eocene amber of France (Diptera: Bombylioidea)
}

\author{
ANDRÉ NEL \\ CNRS UMR 5143, Muséum National d'Histoire Naturelle, Entomologie, 45 rue Buffon, F-75005, Paris, France; \\ e-mail: anel@mnhn.fr
}

Key words. Diptera, Bombyliidae, Mythicomyiidae, Glabellulinae, Phthiriinae, gen. n., sp. n., Lowermost Eocene, French amber

\begin{abstract}
Elektrophthiria magnifica gen. n., sp. n., oldest bee fly of the bombyliid subfamily Phthiriinae, is described from the Lowermost Eocene amber of Oise (France). It suggests at least a Late Cretaceous age for this group, coincident with the diversification of the flowering plants. Eurodoliopteryx inexpectatus gen. n., sp. n., oldest representative of the mythicomyiid subfamily Glabellulinae, is probably the sister genus of extant Doliopteryx, distributed in Africa and the Arabian peninsula, under very arid conditions. This discovery suggests a relatively humid forest close to a river with a drier surrounding area for the palaeoenvironment of the Oise amber.
\end{abstract}

\section{INTRODUCTION}

Bombylioid flies are not rare in the fossil record (Evenhuis, 1991, 1994; Nel \& De Ploëg, 2004). Nevertheless, the known fossils are mainly from the late Eocene, Oligocene or Miocene. Cretaceous and Early Cenozoic bee flies are much less frequent. The Lowermost Eocene amber of Oise is of great interest for our knowledge of the early history of this family, as we have already described one new genus and species of Bombyliidae: Toxophorinae Schiner, 1868 and one Mythicomyiidae Melander, 1902 (Nel \& De Ploëg, 2004). The present fossils are the third and fourth bee flies from this amber, representing the oldest records of the Bombyliidae: Phthiriinae Becker, 1913 and the Mythicomyiidae: Glabellulinae Cockerell, 1914. We follow the body and wing venation terminology of McAlpine (1981).

\section{SYSTEMATICS}

Family Bombyliidae Latreille, 1802

Subfamily Phthiriinae Becker, 1913

Genus Elektrophthiria gen. n.

Type species. Elektrophthiria magnifica gen. n., sp. n.

Diagnosis. Metapleuron covered with micropubescence; mesopleuron bare; male genitalia are rotated $180^{\circ}$, with gonocoxite in dorsal position; gonostylus rather strong, curved, and hook-like; epandrium with a small apical notch; costal vein ending at anal vein; stalk closing the anal cell shorter than cross-vein r-m; a ventral prong on its third antennal segment, of the same length as the dorsal prong; third antennal segment broader in its basal third than at apex and with only four rather long hairs in its basal third.

Etymology. After the Greek "êlektron" for amber and Phthiria.

\section{Elektrophthiria magnifica sp. $\mathbf{n}$.}

(Figs 1-6)
Diagnosis. That of the genus.

Description. Head $0.68 \mathrm{~mm}$ long, $0.80 \mathrm{~mm}$ high, 1.04 mm wide; face absent; postcranium flat; maxillary palp slightly curved, long and slender, one-segmented, rather long, $0.20 \mathrm{~mm}$ long; labrum + labellum $1.0 \mathrm{~mm}$ long; mandible $0.68 \mathrm{~mm}$ long; labrum-epipharynx $0.60 \mathrm{~mm}$ long; clypeus reaching base of antennae; eye $0.50 \mathrm{~mm}$ long, $0.70 \mathrm{~mm}$ high; posterior margin of eye even, without notch; three ocelli disposed in triangle on posterior margin of head; antennae shorter than head; $1^{\text {st }}$ segment of antenna very short, $0.06 \mathrm{~mm}$ long, $2^{\text {nd }}$ segment $0.04 \mathrm{~mm}$ long; $3^{\text {rd }}$ segment (flagellum) $0.26 \mathrm{~mm}$ long, $0.10 \mathrm{~mm}$ wide, broader in its basal third than at apex and with only 5-6 rather long hairs in its basal third, with a very small apical sulcus containing a style, and with a ventral prong as long as dorsal one.

Thorax $1.30 \mathrm{~mm}$ long, $0.90 \mathrm{~mm}$ wide, $1.44 \mathrm{~mm}$ high; mesonotum covered with a dense but short pilosity; mesopleuron with a row of five long hairs along its posterior margin, and numerous hairs along the humeral callosity; metapleuron covered with micropubescence; mesopleuron bare.

Legs long and slender, prothoracic femora $0.90 \mathrm{~mm}$ long, $0.14 \mathrm{~mm}$ wide, tibiae $1.0 \mathrm{~mm}$ long, tarsi $1.10 \mathrm{~mm}$ long; mesothoracic femora $0.84 \mathrm{~mm}$ long, tibiae $1.12 \mathrm{~mm}$ long, tarsi $1.18 \mathrm{~mm}$ long; metathoracic legs nearly completely missing.

Wing $3.24 \mathrm{~mm}$ long, $1.40 \mathrm{~mm}$ wide; R2+3 nearly straight; R4 +5 branched, $0.24 \mathrm{~mm}$ distal of cross-vein $\mathrm{r}-\mathrm{m}$; discal cell $0.96 \mathrm{~mm}$ long, $0.28 \mathrm{~mm}$ wide; $\mathrm{r}-\mathrm{m}$ in its distal third; anal cell closed just before posterior wing margin, with stalk closing anal cell $0.10 \mathrm{~mm}$ long, shorter than cross-vein $\mathrm{r}-\mathrm{m}$ ( $0.12 \mathrm{~mm}$ long); vein M2 present; four postmarginal cells; costal vein ending at anal vein.

Abdomen $1.34 \mathrm{~mm}$ long, about $0.30 \mathrm{~mm}$ wide, covered with long hairs; male genitalia rotated $180^{\circ}$, with gonocoxite in dorsal position; gonostylus rather strong, 


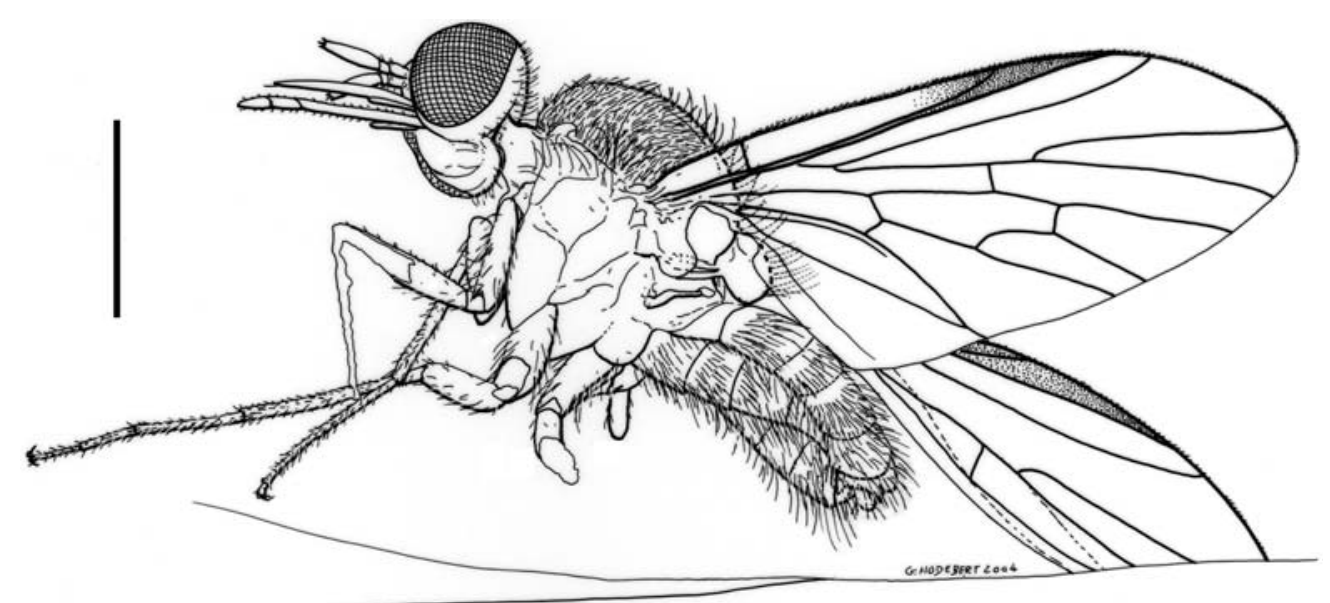

Fig. 1. Elektrophthiria magnifica gen. n., sp. n., holotype PA 208, drawing of general habitus, scale bar - $1 \mathrm{~mm}$.

curved, and hook-like; epandrium with a small apical notch.

Material. Holotype PA 208 (male), deposited in the Laboratoire de Paléontologie, Muséum National d'Histoire Naturelle, Paris.

Etymology. After the wonderful state of preservation of the holotype.

Stratigraphic horizon. Lowermost Eocene, in amber, circa 53 Myr, Sparnacian, level MP7 of the mammal fauna of Dormaal (Feugueur, 1963; Nel et al., 1999).
Type locality. Farm Le Quesnoy, Chevrière, region of Creil, Oise department (north of France).

Discussion. Following the key to families of "Bombyliidae" s.l. of Zaitzev (1992), Elektrophthiria gen. n. would fall in the Phthiriinae Becker, 1913 (= Crocidiinae Hull, 1973 + Mariobezziinae Becker, 1913 + Phthiriinae + Heterotropinae Becker, 1913) because of the following characters: wing with $\mathrm{R} 4+5$ branched; anal cell closed just before posterior wing margin; posterior margin of eye

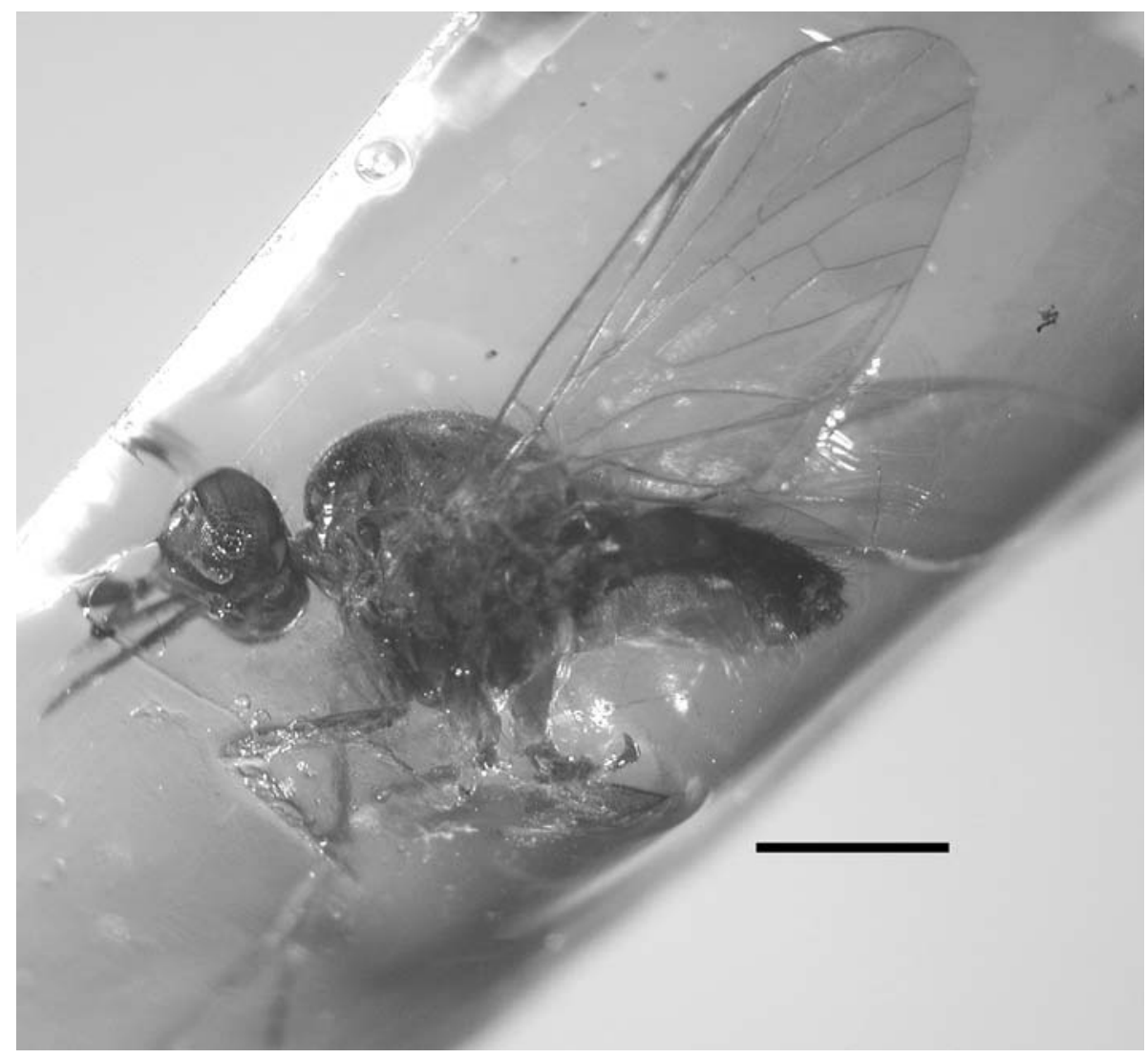

Fig. 2. Elektrophthiria magnifica gen. n., sp. n., holotype PA 208, photograph of general habitus, scale bar - $1 \mathrm{~mm}$. 


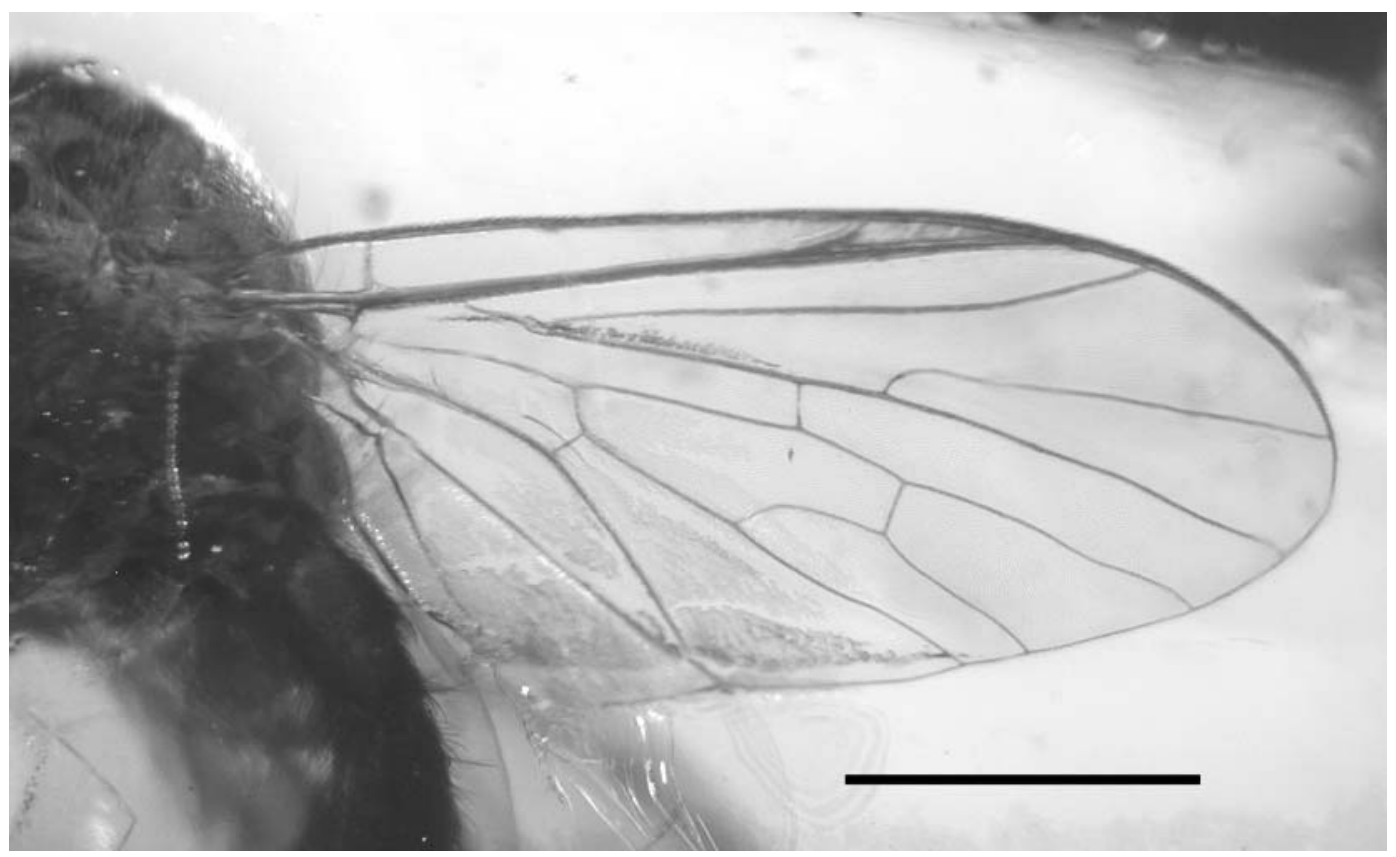

Fig. 3. Elektrophthiria magnifica gen. n., sp. n., holotype PA 208, photograph of wing, scale bar - $1 \mathrm{~mm}$.

even, without notch; antennae shorter than head; $1^{\text {st }}$ segment of antenna very short; vein M2 present and four postmarginal cells. If we follow the phylogenetic analysis of Yeates (1994), Elektrophthiria gen. n. falls in the "Usiinae: Phthiriini" (= Phthiriinae sensu Zaitzev, 1992) because of the following characters: postcranium flat; wing with $\mathrm{R} 4+5$ branched; palps present, long and slender, one-segmented; vein M2 present; flagellum with a very small apical sulcus containing a style (synapomorphy); clypeus reaching base of antennae (synapomorphy). Evenhuis (1990) proposed a revision of this group, as a subfamily Phthiriinae. Following this work, Elektrophthiria gen. n. also falls in this group because of its clypeus reaching the antennal bases and face absent; wing with four posterior cells; antennal sulcus apical. It is much more difficult to precisely ascertain the generic affinities of Elektrophthiria gen. n. within this group because some of the characters proposed by Evenhuis (1990) are difficult to see in the fossil specimens. Nevertheless, the metapleuron of Elektrophthiria gen. n. is covered with micropubescence, an apomorphy of the Phthiriini (sensu Evenhuis, 1990). Its epandrium has a small apical notch, which is plesiomorphic in this group and also in the poecilognathine genus Tmemophlebia Evenhuis, 1986. Its male genitalia are rotated $180^{\circ}$, with gonocoxite in dorsal position, which is also plesiomorphic. Its costal vein ending at anal vein is plesiomorphic. Elektrophthiria gen. n. has a ventral prong on its third antennal segment, which is present in many Phthiriinae. But it is of the same length as the dorsal prong, unlike in Acreotrichus Macquart, 1850. Its mesopleuron is bare, which is a plesiomorphy, while a bare mesopleuron is an apomorphy of the clade (Phthiria + (Acreotrichus \& Pygocona \& Australiphthiria)). Its third antennal segment is broader in its basal third than at apex and with only four rather long hairs in its basal third, very different from those of Acreophthriria Evenhuis, 1986 and Neacrotrichus Cockerell, 1917, sister clade of [Phthiria + (Acreotrichus \& Pygocona \& Australiphthiria)]. Also, the stalk closing the anal cell is shorter than cross-vein r-m, unlike in Acreophthiria. The gonostylus of Elektrophthiria gen. n. is rather strong, curved, and hook-like, unlike that of Neacrotrichus, but more similar to that of Acreophthiria.

Among the fossil taxa, Zaitzev (1992) listed two Oligocene species in the genus Phthiria. First, P. fossa Lewis, 1975 from the Ruby River Basin (USA) is described on a

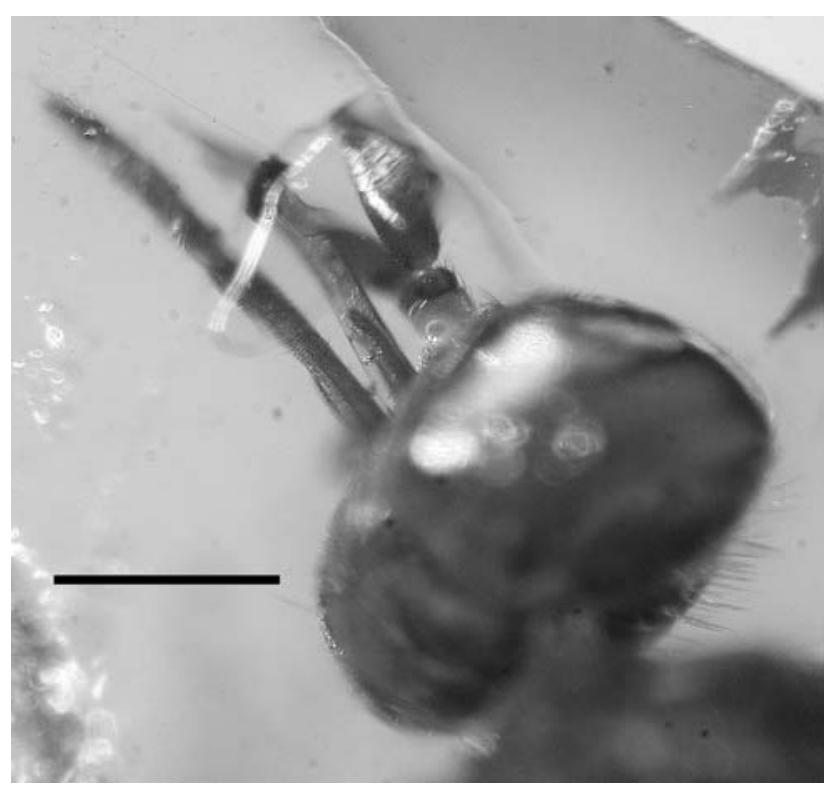

Fig. 4. Elektrophthiria magnifica gen. n., sp. n., holotype PA 208 , photograph of head with mouthparts, scale bar $-0.5 \mathrm{~mm}$. 


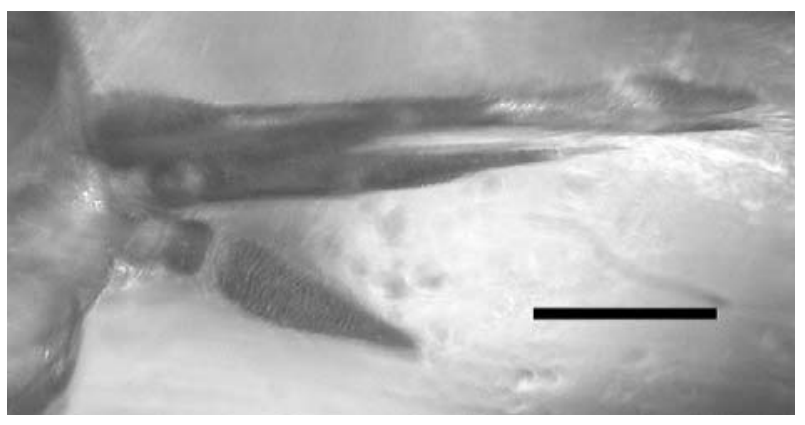

Fig. 5. Elektrophthiria magnifica gen. n., sp. n., holotype PA 208, photograph of antennae, scale bar $-0.2 \mathrm{~mm}$.

well preserved impression on sediments (Lewis, 1975), but the delicate structures of the third antennal segment, thorax pilosity and genitalia are not visible, thus it is not possible to determine with accuracy its exact relationships within the Phthiriinae sensu Evenhuis (1990). Thus its attribution to the genus Phthiria sensu stricto is questionable. After the photograph and drawing of Lewis (1975), $P$. fossa has no or a very short stalk of anal cell, distinctly shorter than in Elektrophthiria gen. n., its wings are dark, unlike the hyaline wings of Elektrophthiria gen. n. Second, P. oligocenica Timon-David, 1943 from the Early Oligocene of Camoins-les-Bains (Marseille Basin, Bouches-du-Rhône, France) is described on a more poorly preserved impression but with the wing venation, some legs, and one antenna in better state. The type specimen is now preserved in the collection of the Musée Longchamp (Marseille). Evenhuis (1994) transferred this fossil to the genus Geron Meigen, 1820, under the incorrect spelling "Geron oligocaenica", without explanation or reexamination of the type material. Numerous characters crucial for a correct classification at subfamily level are not preserved, viz. closure of anal cell, posterior margin of eye, relative lengths of head and antennae, presence of palps, structure of the antennal flagellum, and relative positions of the clypeus and the base of antennae. Nevertheless, its wing venation is very similar to that of Phthiria (see Hull, 1973), especially in the presence of the vein M2. Thus, we prefer to consider it as a Bombyliidae subfamily and genus undetermined, probably related to the Phthiriinae. It differs from Elektrophthiria gen. $\mathrm{n}$. in its longer wings (length about $4.5 \mathrm{~mm}$ ). Other fossil taxa that have been originally placed in the Phthiriinae are now attributed to different bombyliid subfamilies (Evenhuis, 1984, 1990; Zaitzev, 1992).

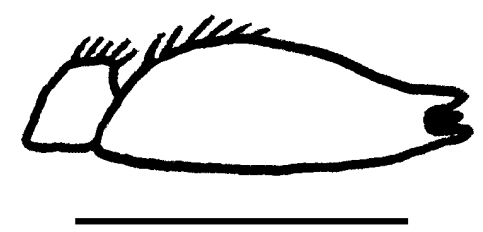

Fig. 6. Elektrophthiria magnifica gen. n., sp. n., holotype PA 208, drawing of second and third antennal segment, scale bar$0.3 \mathrm{~mm}$.
The last fossil Phthiriinae is Poecilognathus stigmalis (Cockerell, 1914). It differs from Elektrophthiria gen. n. in the more basal position of vein r-m. Note that Evenhuis (1994: 335) erroneously attributed this taxon's original description to Cockerell (1915: 643), as this species was described under the combination Geronites stigmalis by Cockerell (1914: 230).

The Recent Phthiriini are found worldwide (Evenhuis, 1990). Thus, little can be inferred about palaeoenvironmental or palaeoclimatology from the present discovery. Recent Phthiriinae are strongly attracted to flowers (Hull, 1973), and their long proboscis, also present in Elektrophthiria, "could have developed as a result of parallel coevolution with the flowering plants" (Zaitzev, 1992). The present discovery supports the presence of Phthiriinae in the very Early Cenozoic and a probable origin of this group during the Late Cretaceous, contemporaneous and maybe in relation with the diversification of the Angiosperms.

\section{Family Mythicomyiidae Melander, 1902 \\ Subfamily Glabellulinae Cockerell, 1914 \\ Genus Eurodoliopteryx gen. n. \\ Type species. Eurodoliopteryx inexpectatus gen. n., sp. n.}

Diagnosis. Vein R2+3 forming a small triangular cell r1; clypeus normal, not strongly developed; cells br and bm confluent, with imperceptible vein $\mathrm{M}$ between them; cell $\mathrm{dm}$ open; vein $\mathrm{CuA2}$ separating from $\mathrm{M}+\mathrm{Cu}$ near the very base of the wing; first antennal flagellomere about $3 \times$ longer than wide; complete sclerotization of the first abdominal tergite; vein R4+5 long; fork of M1+2 and basal portion of M1 present; vein CuA1 connected to postero-distal margin of cell $\mathrm{br}+\mathrm{bm}$.

Etymology. After Europe and the Recent African genus Doliopteryx.

\section{Eurodoliopteryx inexpectatus sp. $\mathbf{n}$.}

(Figs 7-9)

Diagnosis. As for the genus.

Description. Head $0.28 \mathrm{~mm}$ long, $0.44 \mathrm{~mm}$ high; eyes dichoptic but very large; inner eye margin straight; ommatidia of equal size; ocellar tubercle flat; lateral ocelli farther from each other than from anterior ocellus; occiput slightly rounded; frons poorly visible; face not wider than frons; proboscis short, $0.16 \mathrm{~mm}$ long, but only partly visible because of an air bubble; antennal socket situated at middle of inner eye margin; antennal scape very small; pedicel cup-shaped; first flagellomere elongate-lanceolate, about $3 \times$ longer than wide; second flagellomere very long, $0.06 \mathrm{~mm}$ long, with a short apical sensillum.

Thorax $0.64 \mathrm{~mm}$ long, strongly humped when viewed laterally, with microscopic pubescence; scutellum small.

Legs normal in size and shape, with microscopic vestiture.

Wing $1.12 \mathrm{~mm}$ long, $0.48 \mathrm{~mm}$ wide, hyaline; vein $\mathrm{R} 2+3$ very short, meets vein $\mathrm{R} 1$, resulting in small triangular marginal cell; cells br and bm confluent, but with vein $M$ between them still visible as an imperceptible 


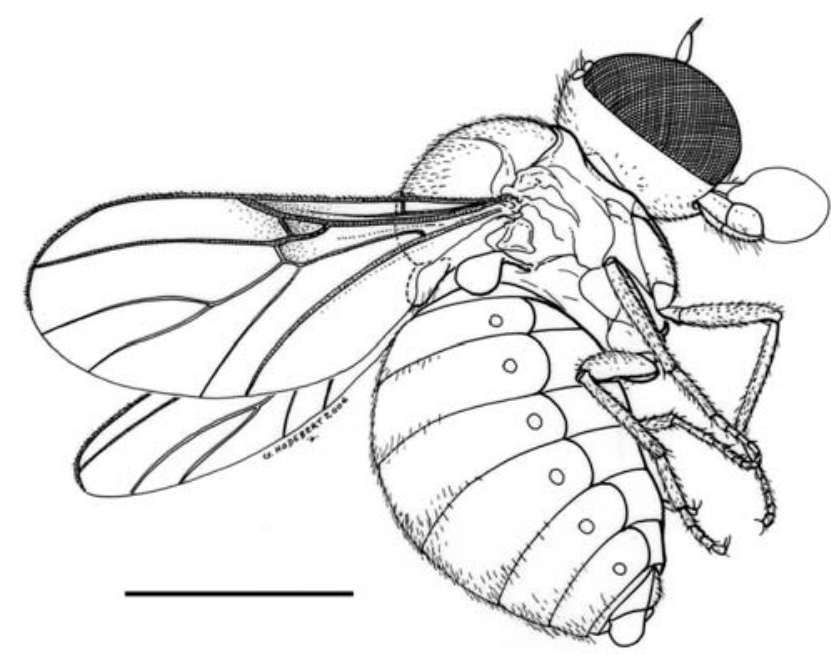

Fig. 7. Eurodoliopteryx inexpectatus sp. n., holotype LQ 193, drawing of general habitus, scale bar $-0.5 \mathrm{~mm}$.

vein, resulting cell narrow, $0.4 \mathrm{~mm}$ long, $0.06 \mathrm{~mm}$ wide; vein M1 and fork of M into M1 and M2 present; cell dm open; vein $\mathrm{CuA} 1$ connected to postero-distal angle of cell br $(+\mathrm{bm})$; $\mathrm{C}$ ends closer to apex of M1 than to that of $\mathrm{R} 4+5$; vein $\mathrm{Sc}$ incomplete; vein $\mathrm{CuA} 2$ separating from $\mathrm{Cu}$ near wing base; anal veins imperceptible; anal lobe small; alula extremely reduced.

Abdomen $0.96 \mathrm{~mm}$ long, broad, elongate-ovoid, and apparently bare; seven visible segments; spiracles on tergites; first tergite complete; no trace of coloration preserved, if present.

Material. Holotype LQ 193, paratypes PA 629 and PA 154 $2-7 / 7$ (six specimens in the same piece of amber), the sex of these fossils cannot be established accurately, deposited in the Laboratoire de Paléontologie, Muséum National d'Histoire Naturelle, Paris.

Etymology. Because of the unexpected presence of a taxon closely related to the Recent Afrotropical and Arabian genus Doliopteryx in the Oise amber.

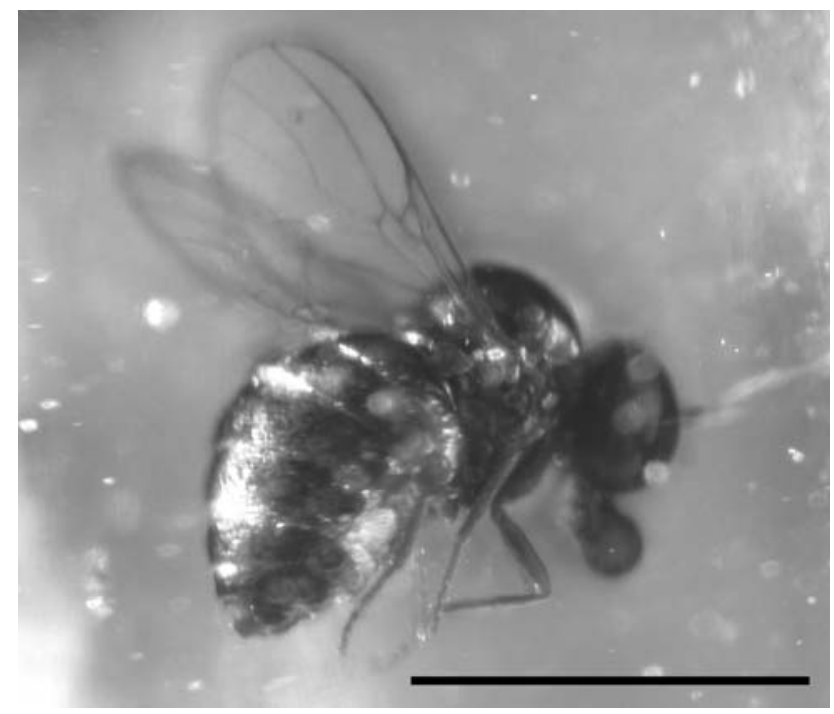

Fig. 8. Eurodoliopteryx inexpectatus sp. n., holotype LQ 193, photograph of general habitus, scale bar $-1 \mathrm{~mm}$.

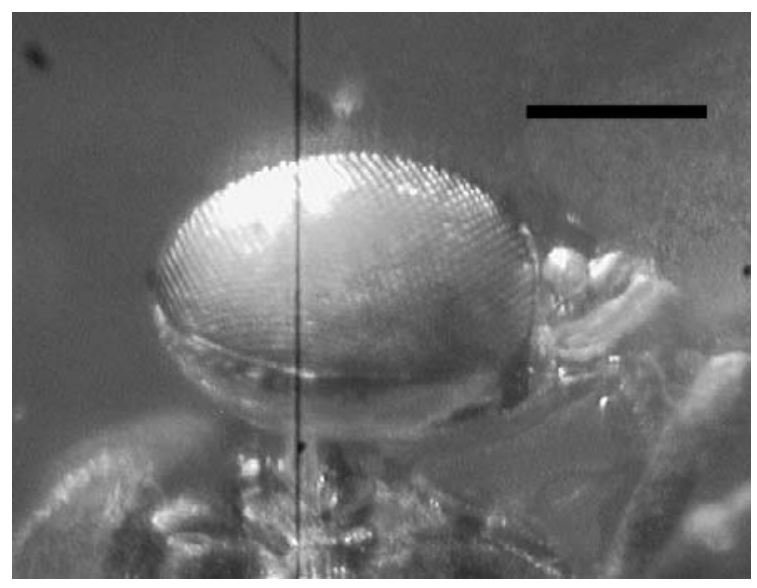

Fig. 9. Eurodoliopteryx inexpectatus sp. n., paratype PA 154 $2 / 7$, photograph of lateral view of head, scale bar $-0.2 \mathrm{~mm}$.

Stratigraphic horizon. Lowermost Eocene, in amber, circa 53 Myr, Sparnacian, level MP7 of the mammal fauna of Dormaal (Feugueur, 1963; Nel et al., 1999).

Type locality. Holotype from Rivecourt, paratypes from Farm Le Quesnoy, Chevrière, region of Creil, Oise department (north of France).

Discussion. Following the key to families of "Bombyliidae" s.l. of Zaitzev (1992), Eurodoliopteryx gen. n. falls in the "Mythicomyiidae" because of the following characters: simple R4+5, head distinctly smaller than large mesothorax, abdominal spiracles on tergites. It also falls in the "Mythicomyiinae" sensu Yeates (1994) because of postcranium flat, $\mathrm{R} 4+5$ simple, palps absent, abdominal spiracles on tergites, costal vein ending between apices of R4+5 and M1. Following the key to mythicomyiid subfamilies of Greathead \& Evenhuis (2001), Eurodoliopteryx falls in the Glabellulinae because of the following characters: $\mathrm{R} 4+5$ ending in costa at a level slightly beyond end of vein M2, R4+5 and M1 diverging at wing margin, costa ending nearer to M1 than to R4+5. Evenhuis (2002a) listed four world genera in this subfamily and Greathead \& Evenhuis (2001) keyed them. Eurodoliopteryx would fall near the Recent genus Doliopteryx Hesse, 1956 because: vein R2+3 forming a small triangular cell r1, clypeus normal, not strongly developed (unlike in genus Mnemomyia Bowden, 1975), and all cells between M2 and $\mathrm{CuA} 2$ confluent (apomorphy). The vein $\mathrm{M}$ between cells br and bm of Eurodoliopteryx is strongly evanescent, evanescent, imperceptible, unlike the strong vein M in Glabellula (Hull, 1973: Fig. 351). We can add that Eurodoliopteryx shares with Doliopteryx the first antennal flagellomere about $3 \times$ longer than wide, and a complete sclerotization of the first abdominal tergite (clearly visible in all specimens), both unlike Glabellula Bezzi, 1902 (Evenhuis, 2000: 120, 2002b: Figs 1-4). Eurodoliopteryx differs from Doliopteryx in its longer vein $\mathrm{R} 4+5$, broader cell br $(+\mathrm{bm})$ and fork of $\mathrm{M} 1+2$ and basal portion of M1 present, not evanescent. The vein CuA1 of Eurodoliopteryx is still connected to postero-distal margin of cell $\mathrm{br}(+\mathrm{bm})$, unlike in Doliopteryx. In the Recent D. crocea Hesse, 1956, it is 
strongly approximate (Evenhuis, 2000: Fig. 26). Eurodoliopteryx shares with Doliopteryx its vein CuA2 separating from $\mathrm{M}+\mathrm{Cu}$ near the very base of the wing (unique character in all Bombylioidea), suggesting a sister genus relationships between the two taxa.

Doliopteryx is distributed in Egypt, Israel, Namibia, Oman, Southern Africa, and Zimbabwe, apparently living in extremely arid regions (Evenhuis, 2000). The probable sister-genus relationships between Doliopteryx and Eurodoliopteryx suggests a similar palaeoenvironment for the Oise amber forest. There is some evidence of a dry season, with forest fires, but there is also strong evidence for the presence of a great quantity of water (rivers, crocodiles, aquatic tortoises) in the same palaeoenvironment. The present discovery suggests a possible reconstruction of the palaeoenvironment of a relatively humid forest along a river, in a surrounding arid area.

The discovery of Eurodoliopteryx in the Early Eocene of Western Europe suggests that the Doliopteryx lineage was not strictly confined to the Arabian and African area in the Tertiary. The subfamily Glabellulinae is widespread, with species in Africa, Western Palaearctic, Nearctic, Neotropical, and Australasian regions. The present discovery is the oldest representative of this subfamily, previously known from Middle to Late Eocene, Oligocene, and Miocene (Evenhuis, 2002a,b).

ACKNOWLEDGEMENTS. We thank the company LafargeGranulat for their help, sampling the fossil, and the family Langlois-Meurinne for the authorization to work in their property. We also thank G. Hodebert (MNHN) for making the drawings, G. De Ploëg (MNHN) for the careful preparation of the holotypes, an anonymous referee and N.L. Evenhuis for their valuable comments on the first version of this paper.

\section{REFERENCES}

Bowden J. 1975: Studies in African Bombyliidae. 10. Taxonomic problems relevant to a catalogue of Ethiopian Bombyliidae, with description of new genera and species. $J$. Entomol. Soc. Sth. Afr. 38: 305-320.

Cockerell T.D.A. 1914: The fossil and recent Bombyliidae compared. Bull. Am. Mus. Nat. Hist. 33: 229-236.

Cockerell T.D.A. 1915: Miocene fossil insects. Proc. Acad. Nat. Sci. (Philadelphia) 66: 634-648.

Evenhuis N.L. 1984: A reassessment of the taxonomic position of the fossil species Protophthiria palpalis and P. atra (Diptera: Bombyliidae). Int. J. Entomol. 26(1-2): 157-161.

EvenHUIS N.L. 1990: Systematics and evolution of the genera in the subfamilies Usiinae and Phthiriinae (Diptera: Bombyliidae) of the World. Entomonograph 11[1989]: 1-78.
EvenHuIS N.L. 1991: World catalog of genus-group names of bee flies (Diptera: Bombyliidae). Bishop Mus. Bull. Entomol. (Honolulu) 5: 1-105.

Evenhuis N.L. 1994: Catalogue of the Fossil Flies of the World (Insecta: Diptera). Backhuys Publishers, Leiden, $570 \mathrm{pp}$.

Evenhuis N.L. 2000: A revision of the "microbombyliid" genus Doliopteryx Hesse (Diptera: Mythicomyiidae). Cimbebasia 16: 117-135.

Evenhuis N.L. 2002a: Catalog of the Mythicomyiidae of the World (Insecta: Diptera). Bishop Mus. Bull. Entomol. (Honolulu) 10: 1-85.

Evenhuis N.L. 2002b: Review of the Tertiary microbombyliids (Diptera: Mythicomyiidae) in Baltic, Bitterfeld, and Dominican amber. Zootaxa 100: 1-15.

Feugueur L. 1963: L'Yprésien du Bassin de Paris. Essai de monographie stratigraphique. Mémoires pour servir à l'explication de la Carte Géologique détaillée de la France, Publication du Ministère de l'Industrie, Paris, 568 pp.

Greathead D.J. \& Evenhuis N.L. 2001: Annotated keys to the genera of African Bombylioidea (Diptera: Bombyliidae; Mythicomyiidae). Afr. Invertebr. 42: 105-224.

Hull F.M. 1973: Bee flies of the World. The genera of the family Bombyliidae. Bull. U. S. Nat. Mus. 286: 1-687.

LEwIS S.E. 1975: A new species of fossil bombyliid (Diptera: Bombyliidae) from the Ruby River basin (Oligocene) of Southwestern Montana. J. Paleontol. 49: 422-429.

McAlpine J.F. 1981: Morphology and terminology - adult. In McAlpine J.F., Peterson B.V., Shewell G.E., Teskey H.J., Vockeroth J.R. \& Wood D.M. (eds): Manual of Nearctic Diptera 1. Research Branch, Agricultural Canada Monograph, Ottawa, pp. 9-63.

Nel A. \& De PloËg G. 2004: New fossil bee flies in the Lowermost Eocene amber of the Paris basin (Diptera: Bombylioidea). Geol. Acta 2(1): 57-65.

Nel A., De Ploëg G., Dejax J., Dutheil D., de Franceschi D., Gheerbrant E., Godinot M., Hervet S., Menier J.-J., Augé M., Bignot G., Cavagnetto C., Duffaud S., Gaudant J., Hua S., Jossang A., de Lapparent de Broin F., Pozzi J.-P., Paicheler J.-C., Bouchet F. \& Rage J.-C. 1999: Un gisement sparnacien exceptionnel à plantes, arthropodes et vertébrés (Éocène basal, MP7): Le Quesnoy (Oise, France). C. R. Acad. Sci. (Sciences de la terre et des planètes) (Paris) 329: 65-72.

Timon-DAVID J. 1943: Insectes fossiles de l'Oligocène inférieur des Camoins 1. Diptères Brachycères. Bull. Soc. Entomol. Fr. 48: $128-134$.

YeAtes D.K. 1994: The cladistics and classification of the Bombyliidae (Diptera: Asiloidea). Bull. Am. Mus. Nat. Hist. 219: 1-191.

Zaitzev V.F. 1992: Contribution to the phylogeny and systematics of the superfamily Bombylioidea (Diptera). Entomol. Rev. 71(4): 94-114.

Received February 16, 2005; revised and accepted September 12, 2005 